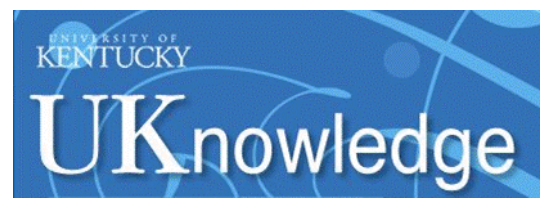

University of Kentucky

UKnowledge

\title{
Economic Injury Level for Bermudagrass Stem Maggot (Diptera: Muscidae) in Bermudagrass Forage Production in Texas
}

V. Corriher-Olson

Texas A\&M AgriLife Extension

A. Knutson

Texas A\&M AgriLife Extension

F. Mitchell

Texas A\&M AgriLife Research

Follow this and additional works at: https://uknowledge.uky.edu/igc

Part of the Plant Sciences Commons, and the Soil Science Commons

This document is available at https://uknowledge.uky.edu/igc/24/2-2/12

The XXIV International Grassland Congress / XI International Rangeland Congress (Sustainable Use of Grassland and Rangeland Resources for Improved Livelihoods) takes place virtually from October 25 through October 29, 2021.

Proceedings edited by the National Organizing Committee of 2021 IGC/IRC Congress

Published by the Kenya Agricultural and Livestock Research Organization

This Event is brought to you for free and open access by the Plant and Soil Sciences at UKnowledge. It has been accepted for inclusion in International Grassland Congress Proceedings by an authorized administrator of UKnowledge. For more information, please contact UKnowledge@lsv.uky.edu. 


\title{
Economic Injury Level for Bermudagrass Stem Maggot (Diptera:
}

\section{Muscidae) in Bermudagrass Forage Production in Texas.}

\author{
Corriher-Olson, $\mathrm{V}^{*}$; Knutson, A. ${ }^{\dagger}$ and Mitchell, $\mathrm{F}^{\star}$. \\ ${ }^{*}$ Texas A\&M AgriLife Extension, Overton, TX; †'Texas A\&M AgriLife Extension, Dallas, TX and *Texas \\ A\&M AgriLife Research, Stephenville, TX.
}

Key words: bermudagrass, forage, economic injury level, bermudagrass stem maggot

\begin{abstract}
The bermudagrass stem maggot, Atherigona reversura Villeneuve, was first reported damaging bermudagrass Cynodon dactylon (L.) Pers grown for forage in 2010 in the southeastern US. Damage results from individual larvae feeding internally on the vascular tissue just above the terminal node of the grass stem. Damage slows plant growth and reduces forage accumulation. To address the need for economic guidelines to manage this new pest, the relationship between the percent of stems damaged by bermudagrass stem maggot and forage yield was measured in commercial bermudagrass hay fields in northcentral Texas during 2016 and 2017. The slope of the linear regression, representing the yield loss per percent stem damage, was used to calculate economic injury levels for a range of hay market values and control costs. The impact of stem damage on protein content, energy and digestibility of bermudagrass hay was also investigated. In this study, percent ADF was positively correlated with bermudagrass stem damage, suggesting that stem damage was associated with increased fiber and reduced digestible energy. TDN was significantly and negatively correlated with increasing bermudagrass stem maggot damage. These results suggest a trend of declining crude protein and energy and an increase in fiber content associated with increasing bermudagrass stem maggot damage. This apparent loss of forage quality is consistent with the observed leaf death and cessation of new growth resulting from bermudagrass stem maggot feeding. However, the $\mathrm{R}^{2}$ value for the relationship between each of these forage quality attributes and stem damage was very low, ranging from $0.03-0.07$, and therefor the impact of stem maggot feeding on forage quality remains unclear and additional studies are needed.
\end{abstract}

\section{Introduction}

The bermudagrass stem maggot (BSM), Atherigona reversura Villeneuve, has become an important pest of bermudagrass, Cynodon dactylon (L.) Pers., forage in the southeastern and southcentral United States. The first reports of crop damage by $A$. reversura in the continental United States were from Georgia, Florida, South Carolina and Alabama, where extensive damage was observed in bermudagrass hay fields and pastures in 2010 (Hudson 2010, Hancock 2012). Subsequently, A. reversura was reported damaging bermudagrass forage throughout the southeastern United States (Hudson et al. 2013, Townsend and Osborne 2013, Baxter et al. 2014). In 2013, A. reversura was observed damaging bermudagrass hay fields in south, east, and central Texas, and in 2015, adults were collected near Lubbock and El Paso, TX.

Baxter et al. $(2014,2017)$ reviewed the general biology of BSM and field characteristics of crop injury. The adults are active low in the grass canopy where they fly rapidly when disturbed. Eggs are deposited on leaves or stems. The neonate larva tunnels into the grass stem above the uppermost node and feeds internally on the newly formed shoot. This feeding damage results in the death of the top two to three leaves which become chlorotic and die, turning white or brown. As a result of leaf death, fields damaged by BSM appear frosted or 'bronzed,' similar to leaf injury resulting from drought, freeze damage, or disease. Stems damaged by BSM can easily be pulled from the leaf sheath due to feeding by the larva, distinguishing them from stems damaged by other factors. The lower stem end shows evidence of larvae feeding and is discolored due to feeding and decay. Damaged stems can also be dissected to reveal the larva if it is still feeding. Mature larvae are cream colored and about $3 \mathrm{~mm}$ in length. Pupation occurs on the soil surface (Baxter et al. 2014). Developmental rates and phenology have not been reported, but adults are active throughout the growing season. Many details of the life cycle of BSM are yet to be reported.

Crop injury is a result of feeding by a single larva that feed internally on the vascular tissue just above the terminal node of the grass stem. The damaged apical shoot stops elongating because of the maggot's feeding injury. As a result, plant growth slows and forage accumulation and yield are reduced (Hancock 2012, Baxter 
et al. 2014, 2017). In Georgia, as much as $80 \%$ of the shoots have been damaged (Hancock 2012, Baxter et al. 2014).

Economic thresholds have been widely used in integrated pest management programs to inform producers when insecticides or other control tactics are necessary to prevent an increasing pest population from causing economic loss greater than the management cots (Pedigo and Rice, 2009). The lowest pest population that results in economic loss is the economic injury level (EIL), and the economic threshold ET, is set below the EIL to allow for the time needed to apply the insecticide or initiate other control tactics before damage exceeds the EIL (Pedigo et al. 1986).

The objective of this study was to quantify the impact of bermudagrass stem maggot BSM damage on bermudagrass forage yield and quality and calculate an EIL to guide management decisions regarding insecticide applications for control of bermudagrass stem maggot. In calculating the EIL, we consider insecticidal control applied within the current hay growth cycle as insecticides have been shown to protect the crop from additional infestation and are widely recommended for control (Layton 2014, Baxter et al. 2017).

\section{Methods and Study Site}

Bermudagrass stem maggot injury and forage yield and quality were measured in commercial fields in northcentral Texas in Comanche, Erath, Denton, and Johnson Counties, where bermudagrass hay is widely grown as forage for beef and dairy cattle. Forage samples were collected by cutting all of the forage within a frame of $0.1 \mathrm{~m}^{2}$ from each of 30 locations within a small area of a field. Each sample $(\mathrm{n}=3$ - per field) was placed in a labelled bag. The number of stem with BSM damage was determined for 50 stems from each forage sample. The 50 stems were returned to the original sample which was then oven dried at $55 \mathrm{C}$ for $72 \mathrm{~h}$, weighed to $0.1 \mathrm{~g}$, and the results were used to calculate yield as $\mathrm{kg}$ dry forage/ha.

\section{Estimating Yield Loss}

The relationship between BSM injury and forage yield was investigated in six bermudagrass hay fields during 2016 and 2017. Except for one field planted to 'Tifton 85', all fields were planted to 'Coastal' bermudagrass. Fields 3 and 4 were rain fed, whereas the remaining fields were irrigated by a center pivot system.

\section{Estimating Loss of Forage Quality}

Five fields were sampled to determine the relationship between BSM injury and forage quality. Samples from Fields 1 and 2 were evaluated for yield and quality, whereas the samples from the other three fields were evaluated only for quality. All were irrigated except for Field 5 in Denton County. The forage samples $(n=30$ per field) collected from these fields were submitted to the Texas A\&M Soil, Water and Forage Testing Laboratory for analysis of crude protein (CP), percent acid detergent fiber (ADF), percent neutral detergent fiber (NDF), and percent total digestible nutrients (TDN) using near-infrared reflectance on dried and ground forage.

\section{Calculating an Economic Injury Level (EIL)}

An EIL, expressed as percentage of stems with visible BSM injury, was calculated as EIL $=C / V I D K$, where $C$ is the cost of insecticide and insecticide application per unit area of production ( $\$ /$ ha), $V$ is the market value per unit of production ( $\$ / \mathrm{kg}$ of dry forage), and $I D$ is the slope of the regression analysis of yield loss across different pest densities or damage (Pedigo et al. 1986, Chasen et al. 2015). The slop, $b$, was estimated from the analysis of covariance as described below. $K$ is proportional reduction in pest attack achieved by the control practice. This value is considered important if the control practice fails to significantly reduce the pest population below the damage boundary or level at which measurable yield loss occurs (Pedigo et al. 1986, Chasen et al. 2015). This is not the case for BSM, as insecticide treatments reduced stem maggot damage by $>90 \%$, and therefore, $K=1$ (Layton 2014).

Economic injury levels were calculated for a range of typical control costs for insecticide and insecticide application and market values for bermudagrass hay. Retail prices of commonly used insecticide labelled for control of BSM in bermudagrass hay were obtained from local suppliers. Average prices for bermudagrass hay for north and central Texas were obtained from the USDA Market News Texas Hay Report (Hutton 2018).

\section{Data Analysis}

Box plots of yield estimates from the six study fields were employed to determine whether the data were uniform and to remove outliers. A single measurement in one field was removed as an outlier, and the remaining 210 samples were used for analytical purposes. The data set was then subjected to an analysis of 
covariance (ANCOVA) using the PROC GLM option of SAS 9.4 (SAS, 2008). The statistical model used field as a categorical variable and the percent stem damage as a predictor of harvest weight. Harvest weight was estimated from stem samples collected and dried as described and converted to $\mathrm{kg} / \mathrm{hectare}$ estimate. Residuals from the overall model were analyzed using PROC UNIVARIATE with the NORMAL option to determine whether the distribution was random, an assumption when using this family of linear models. The Kolmogorov-Smirnov D-test indicated the residual scatter is normal $(P>0.15)$. Results of the analyses were plotted using SigmaPlot 13 (Systat Inc., San Jose, CA).

The forage quality data were subjected to regression analysis using the PROC GLM procedure as described above. Percent CP, ADF, NDF, and TDN were each analyzed over all five fields against bermudagrass stem maggot damage to determine whether damage influence these nutritional factors.

\section{Results \\ Impact of Infestation on Forage Yield}

The overall ANCOVA model for stem injury and forage weight was significant $(\mathrm{F}=55.62, \mathrm{df}=6,203, \mathrm{P}<$ $0.0001, \mathrm{R} 2=0.62$ ). The two model parameters were significant (field $\mathrm{F}=48.05, \mathrm{df}=5, \mathrm{P}<0.0001$, percent stem damage $\mathrm{F}=8.97, \mathrm{df}=1, \mathrm{P}<0.003)$ and the interaction between the two was not $(\mathrm{F}=1.53, \mathrm{df}=5, \mathrm{P}>0.18)$. The slopes of the six lines were parallel and the model estimate for slope was -9.972596 (Fig 1). Model estimates for the line intercepts of individual fields were significantly different and reflected the variable yield potential of each field due to cultivar (Coastal vs. Tifton 85), irrigated versus dryland and fertilizer inputs.

For all fields, yield declined as the percentage of stems with BSM injury increased. The intercept and slope parameters of the model were significant $(P<0.0001, \mathrm{~T}=23.6$ and $P<0.003, \mathrm{~T}=-3.0$, respectively). Parameter estimates for each field were all significant, ranging from $P=0.029$ to $\mathrm{P}<0.0001$. Results from the KolmogorovSmirnov D-test demonstrated the residual scatter to be normal $\left(P>0.15, \mathrm{D}=0.041\right.$ under $\mathrm{H}_{\mathrm{o}}=$ no difference $)$

The EIL is dynamic as it responds to variable costs of insecticide application and crop values. We calculated EILs using published average costs for custom application of pesticides by ground and by air in east Central Texas of $\$ 19.00 / \mathrm{ha}$ (\$7.69/acre) and $\$ 22.04 / \mathrm{ha}$ (\$8.92/acre), respectively (Kloss 2016). The estimated cost of grower-applied insecticide treatment was $\$ 15.96 /$ ha (\$6.45/acre) (Bennett 2018). Local retail costs of labelled insecticides, as determined from informal surveys of pesticide applicators in central Texas, averaged $\$ 9.27 /$ ha (\$3.75/acre) for a generic formulation of lambda-cyhalothrin. Given these estimates, the costs of insecticide plus application were 1) $\$ 25.20 / \mathrm{ha}(\$ 10.20$ /acre) for a grower-applied generic pyrethroid applied by ground, 2) $\$ 28.27 / \mathrm{ha} \mathrm{( \$ 11.44/acre)} \mathrm{for} \mathrm{custom} \mathrm{ground} \mathrm{application} \mathrm{of} \mathrm{generic} \mathrm{pyrethroid} \mathrm{insecticide,} \mathrm{and} \mathrm{3)} \mathrm{\$ 31.31/ha}$ (\$12.67/acre) for aerial application of a generic pyrethroid. As control costs vary according to products, rates and application methods, a series of EILs were calculated for control costs ranging from $\$ 25$ to $\$ 45 / \mathrm{ha}$ at intervals of $\$ 5 /$ ha (Table 1 ).

Market values used in calculating the EIL represented the prices for round bales of coastal bermudagrass hay categories of Premium, Good, and Fair as described by the USDA Market News Service Texas Hay Report (Hutton 2018). These prices vary by season and year according to hay supplies and market demand. Four values, ranging from $\$ 0.07$ to $0.20 / \mathrm{kg}(\$ 0.03-0.09 / \mathrm{lb})$, were selected to represent a seasonal range of prices for these common hay types. A series of EILs was calculated for these variable costs and crop values (Table $1)$. 


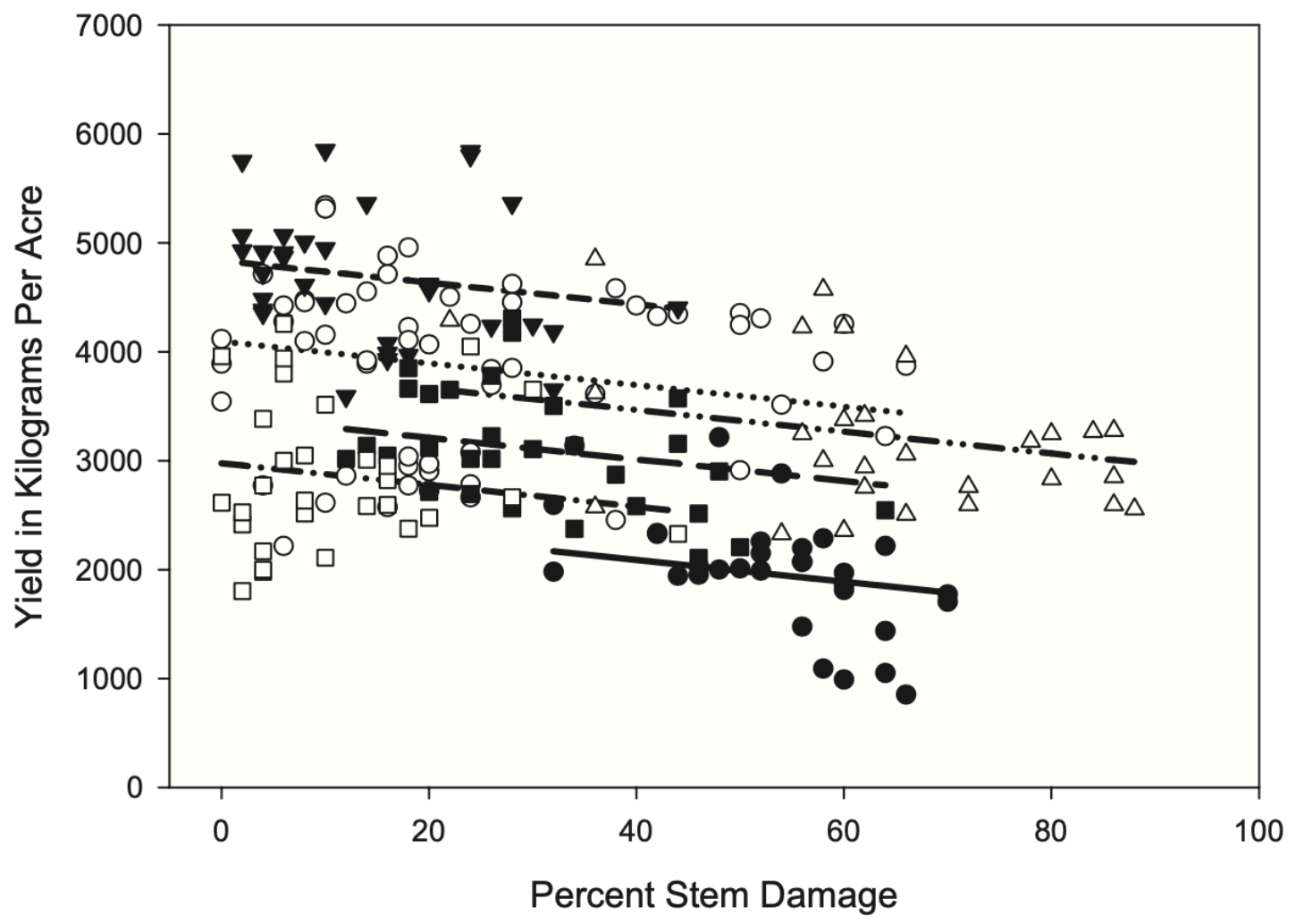

\begin{tabular}{|c|c|c|c|}
\hline \multicolumn{4}{|c|}{ Legend } \\
\hline & Field 1 Predicted Yield & - & Field 1 Actual Yield \\
\hline ............... & Field 2 Predicted Yield & 0 & Field 2 Actual Yield \\
\hline -ー-ー-ー・ & Field 3 Predicted Yield & $\nabla$ & Field 3 Actual Yield \\
\hline$-\cdots-\cdots-\cdot$ & Field 4 Predicted Yield & $\Delta$ & Field 4 Actual Yield \\
\hline--- & Field 5 Predicted Yield & घ & Field 5 Actual Yield \\
\hline -・-・-ー・ & Field 6 Predicted Yield & $\square$ & Field 6 Actual Yield \\
\hline
\end{tabular}

Figure 1. Relationship between percent stem injury by bermudagrass stem maggot and forage yield in six commercial bermudagrass hay fields in northcentral Texas.

Table 1. Economic injury level for bermudagrass stem maggot as percent of injured stems for different hay values and costs of insecticide (\$/acre).

\begin{tabular}{|l|c|c|c|c|c|}
\hline \multirow{2}{*}{$\begin{array}{l}\text { Value of hay } \\
\$\end{array}$} & \multicolumn{5}{|c|}{ Cost of control, \$/ha (\$/acre) } \\
\cline { 2 - 6 } & $25(\$ 10.12)$ & $30(\$ 12.14)$ & $35(\$ 14.16)$ & $40(\$ 16.19)$ & $45(\$ 18.21)$ \\
\hline$\$ 0.20(\$ 0.09)$ & 13 & 15 & 18 & 20 & 23 \\
\hline$\$ 0.15(\$ 0.07)$ & 17 & 20 & 23 & 27 & 30 \\
\hline$\$ 0.11(\$ 0.05)$ & 23 & 27 & 32 & 36 & 41 \\
\hline$\$ 0.07(\$ 0.03)$ & 36 & 43 & 50 & 57 & 64 \\
\hline
\end{tabular}

\section{Impact of Bermudagrass Stem Maggot on Forage Quality}

Bermudagrass stem maggot injury had a significant negative effect on percent crude protein (Fig. 2) and TDN (Fig. 3) and a significant positive effect on percent ADF (Fig. 4). Stem injury was unrelated to percent NDF $\left(F=0.0602, \mathrm{df}=1,147, P=0.0602, R^{2}=0.0238\right)$. However, for all quality measures, stem injury explained very little variability in the model. Attempts to increase model quality by inclusion of field as a parameter resulted in nonsignificance for injury as a parameter. 


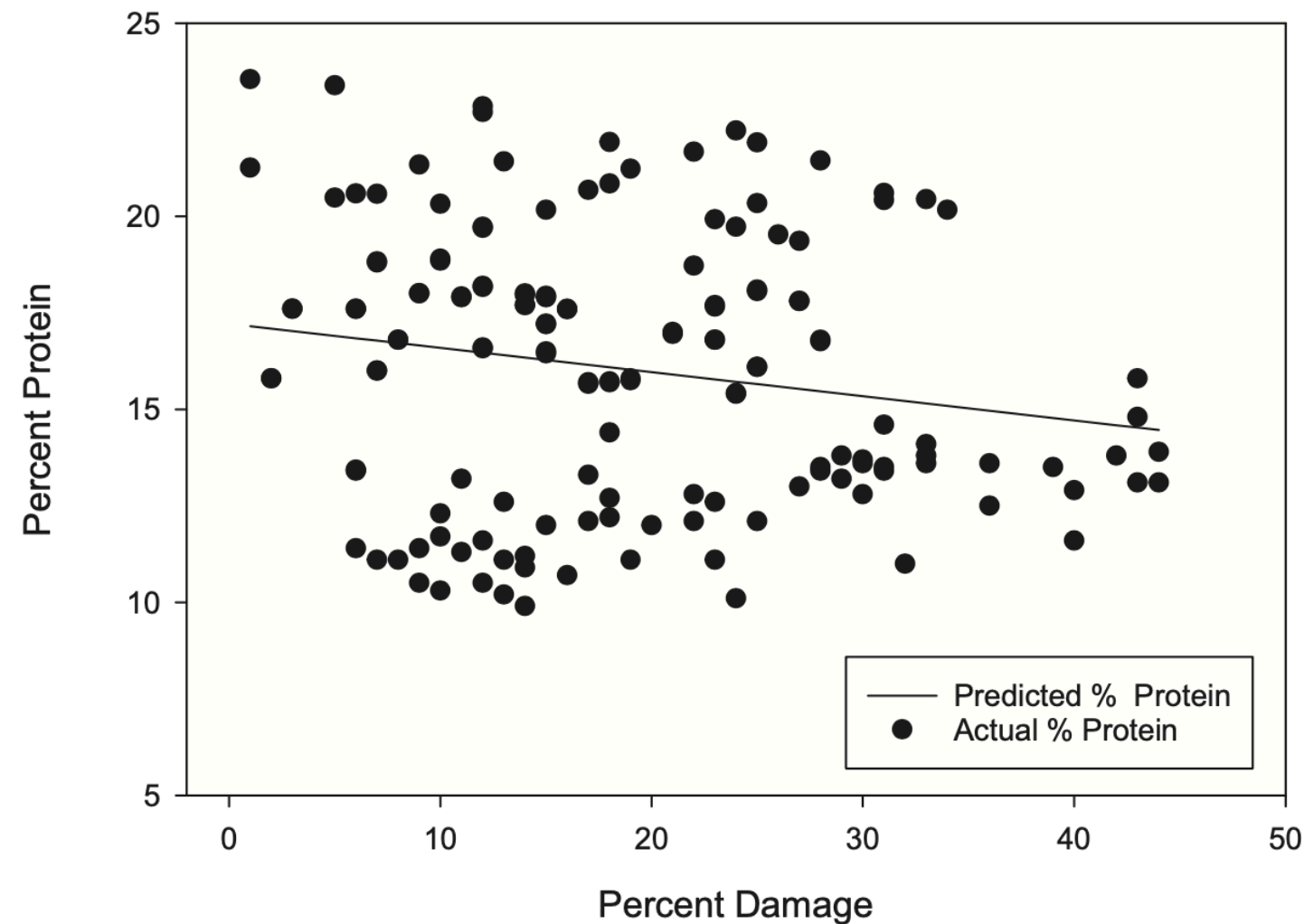

Figure 2. Relationship between percent stem injury by bermudagrass stem maggot and percent crude protein of bermudagrass hay in five fields in northcentral Texas. $y=-0.0625 \mathrm{x}+17.22, P=0.0247, R^{2}=0.0339, F=$ $5.15, \mathrm{df}=1,147$.

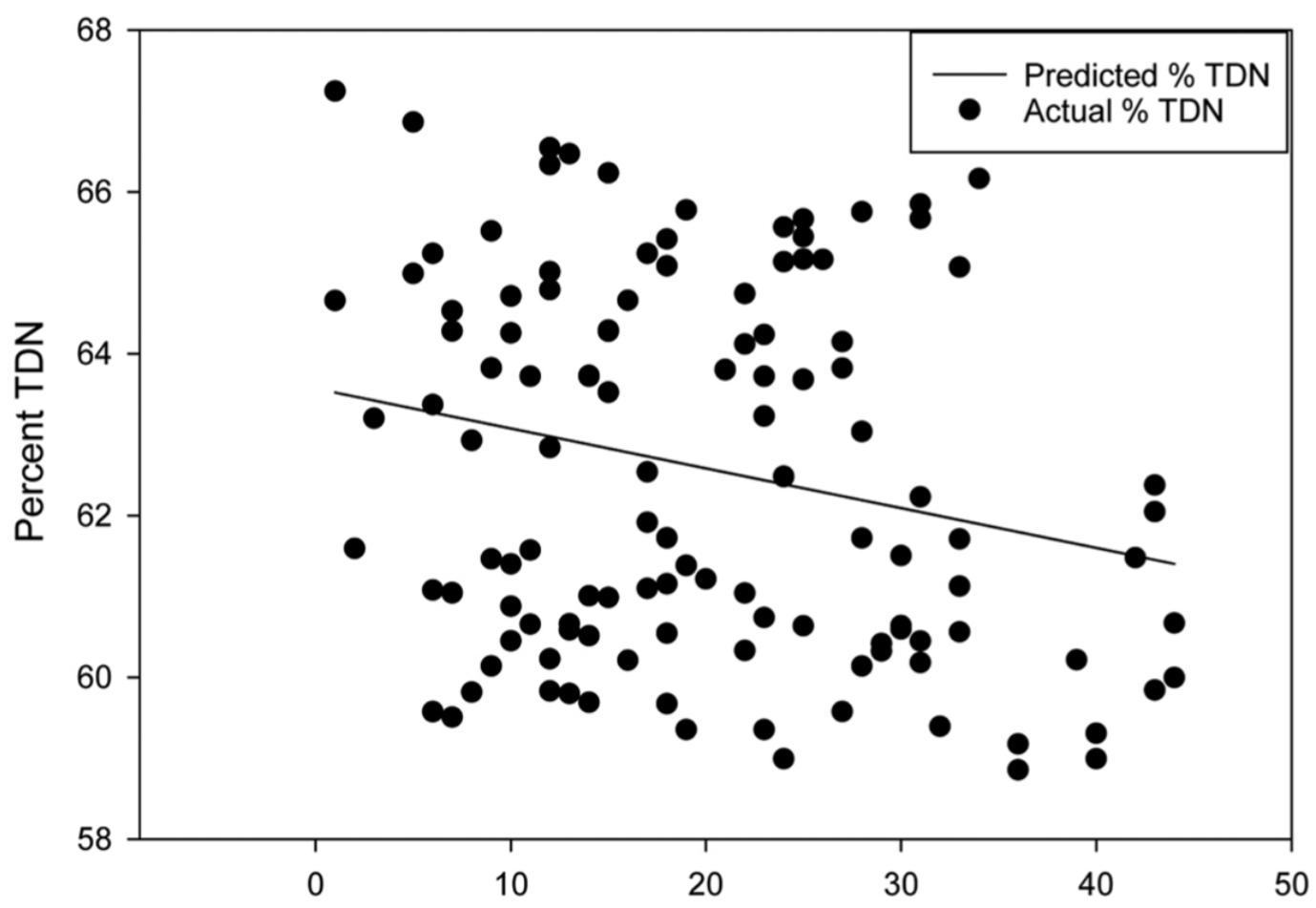

Percent Damage

Figure 3. Relationship between percent stem injury by bermudagrass stem maggot and percent total digestible nutrients in five fields in northcentral Texas. $y=-0.0493 \mathrm{x}+63.57, P=0.0038, R^{2}=0.0553, F=8.63$, $\mathrm{df}=$ 1,147 . 


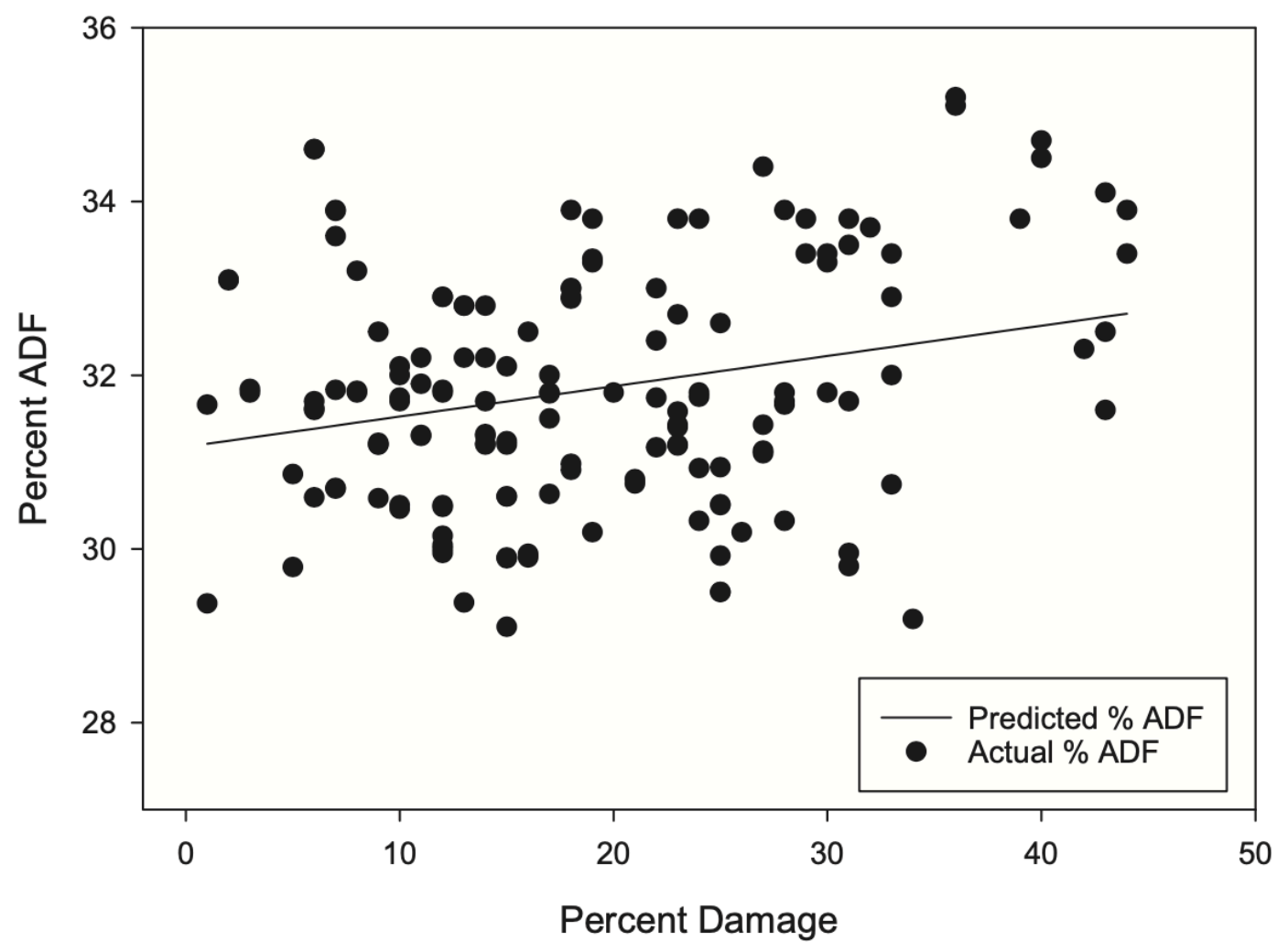

Figure 4. Relationship between percent stem injury by bermudagrass stem maggot and percent ADF of bermudagrass hay in five fields in northcentral Texas. $y=0.03 \mathrm{x}+31.18, P=0.0014, R^{2}=0.0674, F=10.62$, $\mathrm{df}=1,147$.

\section{Discussion [Conclusions/Implications]}

Results of this study demonstrate that BSM injury has a significant negative impact on bermudagrass forage yield. Yield loss was estimated to be $9.97 \mathrm{~kg} / \mathrm{ha}(8.90 \mathrm{lb} / \mathrm{acre})$ for each percentage of stems with BSM injury. Given a typical control cost of a custom application of a generic pyrethroid insecticide at ca. \$30/ha (\$12.14/acre), and a hay value of $\$ 0.11 / \mathrm{kg}(\$ 0.05 / \mathrm{lb})$, the EIL was calculated as $27 \%$ of the stems with BSM injury (Table 1). Mean stem maggot injury exceeded the EIL in three of the six study fields, indicating an insecticide treatment was economically justified in these fields (Table 1). However, if the infestation exceeded the EIL within a week of normal harvest, an early harvest could be considered as an alternative to an insecticide treatment (Baxter et al. 2017).

Additional studies are needed to define the economic threshold, ET, that is, the injury level at which an insecticide should be applied to prevent BSM injury from reaching the EIL. Information is needed on treatment efficacy and rate of control of BSM. At the time of sampling, there are small BSM larvae feeding internally but that have not yet caused leaf injury that is visually evident (without dissecting stems for larvae). These larvae will not be killed by currently labelled insecticides and will therefore contribute some additional yield loss after an insecticide is applied. The impact of these protected larvae, their relationship to when crop injury becomes visible, and the population growth rate will be important in determining the ET.

In this study, BSM infestation levels increased during the season (unpublished data), and except for the sample collected on 5 July 2017 (Field 6), economically damaging infestations were not commonly observed until August-October. This is consistent with observations that damaging infestations do not typically occur until late in the second cutting (harvest) or third cutting in the central and north latitudes of southeastern United States, respectively (Baxter et al. 2017).

\section{Acknowledgements}

This study was supported by a grant from the IPM Enhancement Program provided by the Southern IPM Center. 


\section{References}

Baxter, L.L., D.W. Hancock, and W.G. Hudson. 2014. The Bermudagrass stem maggot (Atherigona reversura Villeneuve): a review of current knowledge. Forage Grazing Lands 12: 1-8.

Baxter, L.L., D.W. Hancock, W.G. Hudson, S.L. Dillard, W.F. Anderson, and B.M. Schwartz. 2015. Response of selected bermudagrass cultivars to bermudagrass stem maggot damage. Crop Sci. 55: 2682-2689.

Baxter, L.L., D.W. Hancock, W.G., Hudson, B. Anderson, and J.J. Tucker. 2017. Managing bermudagrass stem maggot. University of Georgia Extension Bulletin 1484. Athens, GA.

Chasen, E.M., D.J. Undersander, and E.M. Cullen. 2015. Revisiting the economic injury level and economic threshold model for potato leafhopper (Hemiptera: Cicadellidae) in Alfalfa. J. Econ. Entomol. 108:1748-1756.

Hancock, D.W. 2012. Bermudagrass stem maggot. Georgia Cattlemen 40:20.

Hudson, W. 2010. New exotic, invasive fly found damaging bermudagrass forage crops in Georgia. https://secure.caes.uga.edu/ (accessed 6 February 2019).

Hudson, W., D. Hancock, K. Flanders and H. Dorough. 2013. Biology and management of bermudagrass stem maggot. Auburn Cooperative Extension System, Circular ANR- 1462, Auburn, Al. https://www.aces.edu/pubs/docs/A/Anr-1462/Anr-1462.pdf (accessed 6 February 2019).

Hutton, L. 2018. Texas Hay Report. USDA Market News Service, Amarillo, TX. https://www.ams.usda.gov/mnreports/am_gr310.txt (accessed 25 February 2019).

Layton, B. 2014. Control of bermudagrass stem maggot in bermudagrass hayfields, 2013. Arthropod. Manag. Tests 39:F60.

Pedigo, L.P., and M.E. Rice. 2009. Entomology and pest management, $6^{\text {th }}$ ed. Prentice-Hall, Upper Saddle River, NJ.

Pedigo, L.P., S.H. Hutchins, and L.G. Higley. 1986. Economic injury levels in theory and practice. Annu. Rev. Entomol. 31:341-368. 